\title{
INOVASI DAN KREATIVITAS PUBLIC SERVICE DALAM ERA OTONOMI DAERAH SEBAGAI MODERN LOCAL GOVERNMENT
}

\author{
Afifuddin \\ Fakultas Ilmu Administrasi Universitas Islam Malang \\ Jalan MT. Haryono No. 193 Malang, 65144, 0341 551932, Fax:0341 552249 \\ E-mail : afifuddin@unisma.ac.id
}

\begin{abstract}
The implementation of public services is still going on with the old public administration practices. Therefore, it is time for the bureaucracy to change its mindset. The development of the paradigm of public administration can bring enlightenment to the bureaucracy. Public Service innovation and creativity is one of the right solutions in the era of regional autonomy in achieving the welfare of modern regional government. So that innovation and creativity are needed to translate public interest in accelerating the goal of regional autonomy, namely nation building. This study raised the formulation of the problem; (1). How is the innovation and creativity of public service in the era of regional autonomy as a modern local government? (2). What are the supporting and inhibiting factors for implementing innovation and creativity in public service in the era of regional autonomy as modern local government in Indonesia? This study was designed using qualitative methods with interactive techniques. The results of this study are expected to find new concepts that can be applied in improving public services in Indonesia, and to realize these innovations the government needs space for creativity.
\end{abstract}

Keywords : Innovation, Creativity, Era of Regional Autonomy.

ABSTRAK
Penyelenggarakan pelayanan publik masih saja terjadi praktik-praktik old public administration. Oleh karena itu sudah saatnya birokrasi merubah mindsetnya. Perkembangan paradigma administrasi publik dapat membawa pencerahan bagi birokrasi. Inovasi dan kreativitas Public Service merupakan salah satu solusi yang tepat di era otonomi daerah dalam mencapai kesejahteraan pemerintahan daerah yang modern. Sehingga Inovasi dan kreativitas sangat di perlukan untuk menerjemahkan public interest dalam mempercepat tujuan otonomi daerah yaitu nation building. Penelitian ini mengangkat rumusan masalah; (1). Bagaimanakah inovasi dan kreativitas public service dalam era otonomi daerah sebagai modern local government?, (2). Apa saja faktor pendukung dan penghambat penerapan inovasi dan kreativitas public service dalam Era otonomi daerah sebagai modern local government di Indonesia?. Penelitian ini dirancang menggunakan metode kualitatif dengan teknik interaktif. Hasil penelitian ini diharapkan dapat menemukan konsep baru yang dapat diaplikasikan dalam peningkatan public service di Indonesia, dan untuk mewujudkan inovasi tersebut pemerintah perlu ruang untuk berkreasi.

Kata Kunci : Inovasi, Kreativitas, Era Otonomi Daerah..

\section{PENDAHULUAN}

Tujuan dari terbentuknya Pemerintahan

Negara Indonesia adalah melindungi segenap

bangsa Indonesia dan seluruh tumpah darah

Indonesia dan untuk memajukan

kesejahteraan umum, mencerdaskan kehidupan bangsa, dan ikut melaksanakan ketertiban dunia yang berdasarkan kemerdekaan, perdamaian abadi dan keadilan sosial, maka disusunlah Kemerdekaan Kebangsaan Indonesia itu dalam suatu Undang - Undang Dasar Negara Indonesia. ${ }^{1}$

\footnotetext{
1 Undang-Undang Dasar 1945.
} 
Untuk merealisasikan tujuan tersebut dan lebih dekat dengan pelayanan masyarakat maka otonomi daerah penjadi salah satu cara untuk lebih memberikan kewenangan kepada daerah dalam memberikan publik service sesuai dengan kondisi wilayah masing-masing daerah.

Pelayanan publik adalah kegiatan atau rangkaian kegiatan dalam rangka pemenuhan kebutuhan pelayanan sesuai dengan peraturan perundang-undangan bagi setiap warga negara dan penduduk atas barang, jasa, dan/atau pelayanan administratif yang disediakan oleh penyelenggara pelayanan publik. $^{2}$

Inovasi dan kreativitas public service di Daerah adalah semua bentuk pembaharuan dalam penyelenggaraan Pemerintahan Daerah $^{3}$. Sasaran inovasi daerah diarahkan untuk mempercepat terwujudnya kesejahteraan masyarakat melalui peningkatan pelayanan publik di Era Otonomi Daerah sebagai modern local government.

Di masa otonomi daerah, banyak kabupaten/kota ternyata belum mampu mewujudkan pelayanan publik yang efektif. Permasalahan pelayanan publik yang tidak efektif ini dipicu oleh berbagai hal yang kompleks mulai dari budaya birokrasi, rendahnya kemampuan aparat birokrasi untuk melakukan diskresi, serta kelangkaan komitmen pimpinan daerah untuk menciptakan pelayanan publik yang responsif, akuntabel, dan transparan. Artinya bahwa penyelenggaraan pemerintahan masih ditandai dengan praktek-praktek old public administration. ${ }^{4}$

Penyelenggaraan pemerintahan daerah diarahkan untuk mempercepat terwujudnya kesejahteraan masyarakat melalui peningkatan pelayanan, pemberdayaan, dan peran serta masyarakat, serta peningkatan daya saing daerah dengan memperhatikan prinsip demokrasi, pemerataan, keadilan, dan kekhasan suatu daerah dalam sistem Negara Kesatuan Republik Indonesia. ${ }^{5}$

Selama ini pemerintah khususnya birokrasi di daerah telah gagal melakukan upaya penyelenggaraan pelayanan publik yang mengedepankan penghargaan terhadap hak dan kewajiban serta martabat masyarakat sebagai warga negara. Efek negatifnya adalah masyarakat sudah tidak lagi memiliki hak dan martabat dalam pelayanan publik. Hal ini menyebabkan posisi tawar masyarakat menjadi rendah dalam menerima berbagai jenis pelayanan publik. Lemahnya posisi tawar masyarakat dalam pelayanan ini seringkali muncul karena persepsi birokrasi terhadap pengguna jasa hanyalah sebatas

\footnotetext{
2 Undang-Undang Nomor 25 Tahun 2009 Tentang Pelayanan Publik.

3 Peraturan Pemerintah Nomor 38 Tahun 2017 Tentang Inovasi Daerah.

4 Mifta Thoha, (2015), Ilmu Administrasi Publik Kontemporer, Jakarta; Prenadamedia Group, Hlm. 72.

5 Undang-Undang Nomor 23 Tahun 2014 Tentang Pemerintahan Daerah.
} 
pelanggan. Karenanya pelanggan bukanlah orang yang memiliki hak dan kewajiban dalam pelayanan publik.

Untuk mengakomodasi aspirasi kemajemukan masyarakat maka model desentralisasi dengan perwujudannya sebagai Otonomi Daerah, ${ }^{6}$ perlu untuk diimplementasikan. Dengan otonomi daerah, pelayanan publik lebih didekatkan pada masyarakat, misalnya desentralisasi kesehatan sebagai upaya pemberian layanan kesehatan yang responsif. Namun pada kenyataannya masih banyak terjadi masyarakat miskin yang belum mendapatkan layanan kesehatan dengan baik. Belum semua warga miskin tertampung dalam program pelayanan kesehatan untuk masyarakat miskin (Askeskin). Daerah tidak memiliki ukuran yang jelas berkaitan dengan ukuran warga miskin sesuai dengan karakteristik daerah, yang digunakan adalah ukuran Badan Pusat Statistik (BPS) seperti kondisi rumah, kepemilikan kendaraan, anggota keluarga, pendapatan minimal dan sebagainya. Sehingga hal ini dimanfaatkan oleh banyak pihak untuk merekayasa atau menyalahgunakan kewenangan untuk menentukan sasaran, termasuk juga didalamnya persoalan politik karena menyangkut janji-janji wakil rakyat pada saat kampanye dan persoalan kemampuan anggaran daerah juga.
Dengan demikian dapat disimpulkan bahwa kegagalan pemerintah daerah dalam program pelayanan bagi masyarakat miskin sangat berkaitan dengan kapasitas manajemen pemerintah daerah dan juga aspek politik yang ada di daerah. Kapasitas manajemen berkaitan dengan kemampuan sumber daya manusia, kapasitas informasi terkait dengan sistem informasi dan juga kapasitas anggaran daerah. Oleh karena itu perlu adanya upaya modernisasi penyelenggraan pemerintahan di daerah (modern local government) untuk pencapaian tujuan otonomi daerah yang sesungguhnya.

Penyelenggaraan pemerintahan di daerah sekarang ini harus menyesuaikan diri dengan perubahan. Perkembangan wacana perubahan sebenarnya telah dimulai sejak 1960an, baik dikalangan ilmuwan maupun praktisi di Amerika-Eropa dan juga Indonesia. Berbagai macam pemikiran bermunculan mewarnai era perubahan yang di Indonesia menjadi retorika yang luar biasa berkembangnya. Dengan jargon reformasi birokrasi, semua orang bicara perubahan. Good governance, electronic governance, dynamic governance dan sekarang muncul sound governance merupakan konsep impor yang sedang banyak dikaji orang sebagai alat reformasi birokrasi.

Tugas dari Kepala Daerah salah satunya adalah memelihara ketenteraman dan

\footnotetext{
6 Bhennyamin Hoessein, (2021), Hubungan Penyelenggaraan Pemerintahan Pusat dengan Pemerintahan Daerah, Jurnal Bisnis dan Birokrasi, Vol. 1, No. 1, Hlm. 9.
} 
ketertiban masyarakat, ${ }^{7}$ sehingga Pemerintah Daerah dalam menjalankan birokrasi harus mengedepankan kepentingan masyarakat. Dengan demikian dapat dikatakan bahwa birokrasi merupakan agen utama bagi perubahan. Perubahan dalam pelayanan publik merupakan konsekuensi otonomi daerah menjadi tanggung jawab daerah. Dan hal ini merupakan peluang sekaligus tantangan dalam penyelenggaraan otonomi daerah. Karena adanya otonomi daerah, ada tersedia banyak peluang dan tantangan bagi daerah. Terutama dalam hal penyelenggaraan pelayanan publik. Salah satunya adalah melalui upaya modernisasi penyelenggaraan pemerintahan daerah (modern local government).

Modernisasi pemerintah lokal penting dilakukan seiring dengan adanya perkembangan wacana perubahan. Pemerintah sebagai agen perubahan harus menerapkan berbagai prinsip baru dalam penyelenggaraan pemerintahan. Penerapan ini bukan sekedar adopsi akan tetapi lebih kepada penerapan nilai-nilai mendasar yang sesuai dengan karakteristik lokal (local wishdom). Dengan demikian daerah tidak akan kehilangan akar budaya yang melekat. Untuk itulah tulisan ini mencoba memberi gambaran terkait dengan berbagai pendekatan penting yang dapat digunakan untuk memodernkan penyelenggaraan daerah.
Di indonesia implementasi Otonomi Daerah sangat sesuai dengan kondisi geografis dan sosio kultural masyarakat Indonesia. Kemajemukan ini merupakan konsekuensi dari sebuah negara yang terdiri dari banyak pulau, kebudayaan, ras, suku dan bangsa. Sehingga rumusan masalah yang bisa di ajukan adalah; 1. Bagaimanakah Inovasi dan kreativitas public service dalam era otonomi daerah sebagai modern local government. 2. Apa saja faktor pendukung dan penghambat penerapan inovasi dan kreativitas public service dalam era otonomi daerah sebagai modern local government di Indonesia.

Sedangkan metode penelitian yang digunakan adalah metode kualitatif dengan teknik interaktif. Metode ini sangat tepat digunakan karena menyesuaikan dengan kondisi geografis dan masyarakat Indonesia yang sangat majemuk. Metode ini sifatnya eksploratif sehingga lebih cocok untuk mengupas faktor pendukung, penghambat dan faktor kegagalan penerapan Otonomi Daerah dengan lebih jelas dan mendalam

\section{PEMBAHASAN}

\section{Perkembangan Paradigma Administrasi Publik Dalam Konteks Pelayanan Publik}

Akar permasalahan dalam pelayanan publik adalah karena mindset melayani tidak pernah ada dalam diri birokrasi. Selama ini justru birokrasilah yang minta dilayani. Oleh

\footnotetext{
7 Undang-Undang Nomor 9 Tahun 2015 Tentang Perubahan Kedua Atas Undang-Undang Nomor 23 Tahun 2014 Tentang Pemerintahan Daerah.
} 
karena itu apapun bentuk kelembagaannya, kalau mindset birokrasi sebagai pelayan publik belum ditanamkan dalam diri birokrasi maka pelayanan publik akan tetap pada kondisi buruk. Mindset yang dimaksud dalam birokrasi pelayanan adalah mindset birokrasi yang masih mengedepankan pendekatan administrasi yang tradisional. Pendekatan administrasi publik tradisional (old publik administration), menurut Denhardt dan Denhardt memiliki ciri dominan sebagai berikut: $^{8}$

1. Administrasi publik cenderung punya peran yang terbatas dalam proses perumusan kebijakan publik, sedangkan peran utama lebih pada upaya mengimplementasikan kebijakan publik.

2. Pemberian pelayanan dilaksanakan oleh para administrator yang harus bertanggung jawab kepada pejabat politik dan diberi diskresi (keleluasaan) yang sangat terbatas.

3. Program-program publik dikelola oleh organisasi yang disusun secara hierarkis dimana para pemimpin mengontrol dari atas ke bawah.

4. Tujuan utama yang hendak dicapai pemerintah adalah efisiensi dan rasionalitas.
5. Apabila ingin efisien, organisasi publik harus dikelola dengan system tertutup dimana keterlibatan warga masyarakat sangat terbatas atau dibatasi.

6. Tugas utama administrasi publik adalah melaksanakan fungsi teknis administrasi seperti POSDCORB (Panning, Organizing, Staffing, Directing, Controlling, dan Budgeting). ${ }^{9}$

Dengan model pendekatan yang dicirikan dalam old public administration, maka pelayanan publik yang diberikan merupakan bentuk tugas pemerintah sebagai penguasa yang telah diberi hak untuk mengatur masyarakat. Sehingga keterlibatan masyarakat memang sangat rendah. Artinya dalam pelayanan publik model ini tidak ada nilai-nilai ekonomi dan demokrasi yang dijadikan landasan dalam bertindak.

Mewabahnya reinventing goverment menyebabkan pemerintah daerah bereforia melakukan perubahan. Perubahan-perubahan tersebut diantaranya dengan melakukan model pelayanan swasta untuk pelayanan publik. Misalnya di kantor perijinan prosedur pelayanan dirubah menjadi lebih simpel. Kemudian pemerintah daerah membuat Standar Pelayanan Minimum (SPM) yang harus dipenuhi baik oleh masyarakat sebagai pengguna jasa maupun petugas layanan.

\footnotetext{
8 Denhardt dan Denhardt, (2003), The New Public Service, Serving not Steering, New York; M.E. Sharpe, Armonk, Hlm. (__ $)$.

9 Keban Yeremis T, (2014), Enam Dimensi Strategis Administrasi Publik, Konsep, Teori dan Isu. (__ $)$; (_ $)$, Hlm.
} 
Dalam SPM memuat persyaratan perizinan, waktu yang diperlukan dan juga sanksi bagi petugas. Dalam istilah lain SPM sebenarnya mengadopsi model costumer's charter. Selain itu secara fisik (tangiable) layanan petugas juga berubah. Ada model front office, kemudian mekanisme pengaduan dan seragam petugaspun dibuat berbeda dengan pegawai negeri yang tidak melakukan pelayanan.

Perubahan-perubahan tersebut merupakan gambaran perkembangan mindset pemerintah daerah ke arah manajemen publik baru atau New Public Management (NPM). Pendekatan manajemen publik baru lahir sebagai akibat dari ketidakpuasan terhadap praktek-praktek penyelenggaraan administrasi publik, seperti misalnya pelayanan publik. Praktek pelayanan publik selama ini cenderung dilakukan melalui model birokrasi weberian, seperti stuktur hirarkhis yang kemudian berakibat pada ketidakefisienan, ekonomi biaya tinggi, prosedur yang kaku, dan budaya suap.

Di samping itu, adanya perubahan lingkungan administrasi publik yang sangat besar seperti teknologi informasi, demokrasi, dan liberalisasi, telah mendorong dilakukannya reformasi administrasi publik. Tuntutan ini kemudian secara teoretis direspon dengan munculnya pendekatan manajemen publik baru (new public management), yang ditandai dengan dengan munculnya konsep managerialism dari Pollit ${ }^{10}$, konsep new public management yang dikembangkan oleh Hood ${ }^{11}$, konsep marketbased public administration ${ }^{12}$, dan konsep reinventing government ${ }^{13}$. Konsep-konsep dalam manajemen publik baru ini sangat diwarnai oleh teori pasar (market theory) dan teori pilihan publik baru (new public choice theory) ${ }^{14}$.

Owen E. Hughes 15 menyebutkan adanya enam alasan utama munculnya paradigma manajemen publik baru, yaitu:

1. Administrasi publik tradisional telah gagal mencapai tujuannya secara efektif dan efisien sehingga perlu dirubah menuju ke orientasi yang lebih memusatkan perhatiannya pada kinerja dan akuntabilitas.

10 Christopher Pollitt (1990), Managerialism and the Public Services: The Anglo- American Experience. Cambridge, Massachusetts; Basil Blackwell, Hlm.

11 C. Hood, (1991), A Public Management for All Seasons? Public Administration, Spring, Vol. (__ $)$, No. (__ $)$, Hlm. 3-19.

12 C. Hood, (1995), The NPM in the 1980s: Variations on a Theme, Accounting, Organisation and Society, Vol. 2, No. 3, Hlm. 93-110.

13 David Osborne dan Ted Gaebler, (1992), Mewirausahakan Birokrasi : Mentransformasi Semangat Wirausaha Ke Dalam Sektor Publik, Jakarta; PPM, Hlm

14 B. Guy Peters, (1995), The Politics of Bureaucracy, Massachusetts; Addison Wesley, Hlm. (__).

15 Owen E. Hughes, (1994), Public Management and Administration: An Introduction, London: The MacMillan Press Ltd, Hlm. 
2. Adanya dorongan kuat untuk mengganti tipe birokrasi klasik yang kaku menuju kondisi organisasi publik, kepegawaian, dan pekerjaan ke arah yang lebih fleksibel.

3. Perlunya menetapkan tujuan organisasi dan pribadi secara lebih jelas dan ditetapkannya tolak ukur capaian kinerja melalui indikator kinerja.

4. Perlunya setiap pegawai senior memiliki komitmen politik pada pemerintah daripada sekadar bersikap netral atau nonpartisan.

5. Fungsi-fungsi yang dijalankan pemerintah hendaknya lebih disesuaikan dengan tuntutan dan sinyal pasar.

6. Adanya kecenderungan untuk mereduksi peran dan fungsi pemerintah dengan melakukan kontrak kerja dengan pihak lain (contracting out) dan privatisasi.

Konsep new public management menurut Hood $^{16}$ memiliki karakteristik sebagai berikut:

1. Lebih berfokus pada manajemen bukan pada kebijakan, utamanya pada terwujudnya sebuah manajemen yang profesional dalam sektor pelayanan publik. Sebuah corak manajemen yang aktif, kompeten, dan memiliki keleluasaan untuk mengendalikan jalannya kehidupan sebuah organisasi sebagai prasyarat untuk mendorong adanya akuntabilitas atas tindakan yang telah dilakukan.
2. Adanya standar yang jelas dan dilakukannya pengukuran terhadap kinerja yang dicapainya. Untuk itu, tujuan dan target kinerja harus dirumuskan dan ditetapkan dengan jelas.

3. Penekanan yang lebih besar pada pengendalian atas hasil (output) bukan pada prosedur. Dengan demikian, aneka sumber daya benar-benar dialokasikan pada sasaran untuk mencapai target kinerja yang akan diukur.

4. Pergeseran ke arah adanya tingkat persaingan yang lebih besar di dalam sektor pelayanan publik, baik melalui penerapan mekanisme kontrak dengan jangka waktu yang terbatas, mekanisme tender, maupun mekanisme penggunaan insentif moneter dan kebebasan dalam praktek manajemen sektor publik.

5. Penekanan pada pola-pola manajemen sebagaimana dipraktekkan dalam sektor swasta untuk mendukung perbaikan kinerja pelayanan publik, utamanya penereapan prinsip fleksibilitas dalam ikatan kerja maupun pemberian imbalan atau penggajian.

6. Adanya pergeseran ke arah pemecahan ke dalam berbagai unit organisasi yang lebih kecil dalam sektor pelayanan publik. Unitunit organisasi yang besar dibagi ke dalam sejumlah unit organisasi yang lebih kecil yang diorganisasikan berdasarkan pada

16 C. Hood. I., Lo.cit. 
182 Yurispruden Volume 4, Nomor 2, Juni 2021, Halaman 175. -192.

produk layanan yang akan diberikan. Dengan demikian, akan mendorong terciptanya sebuah unit organisasi yang lebih memungkinkan untuk dapat dikelola secara lebih baik.

7. Penekanan yang lebih besar pada disiplin dan parsimoni dalam penggunaan sumberdaya, utamanya untuk mendukung kemungkinan dilakukannya pengurangan terhadap beban biaya langsung, peningkatan terhadap beban biaya langsung, peningkatan disiplin pegawai mengurangi sikap tidak responsif terhadap tuntutan dari serikat pekerja, dan mengurangi biaya atas tuntutan ganti rugi yang sering kali muncul (Hughes). ${ }^{17}$

Prinsip yang hampir sama juga dikemukakan oleh Osborne dan Gaebler ${ }^{18}$ melalui konsepnya reinventing government guna mendukung tumbuhnya model pemerintahan baru yang disebutnya entrepreneurial government.

Di dalam konsep new public management semua pimpinan (manager) di dorong untuk menemukan cara-cara baru dan inovatif untuk memperoleh hasil yang maksimal atau melakukan privatisasi terhadap fungsi-fungsi pemerintahan. Mereka tidak lagi memimpin dengan cara-cara melakukan semuanya sampai jenis pekerjaan yang sekecil-kecilnya. Mereka tidak lagi melakukan "rowing" melaksanakan semua pekerjaan, melainkan mereka melakukan "steering" membatasi terhadap pekerjaan atau fungsi mengendalikan, memimpin, mengarahkan yang strategis saja dengan demikian, fungsi dari New Public Management adalah sangat menitik beratkan pada mekanisme pasar dalam mengarahkan program-program publik.

Konsep new public management dapat dipandang sebagai suatu konsep baru yang ingin menghilangkan monopoli pelayanan yang tidak efisien yang dilakukan oleh instansi dan pejabat-pejabat pemerintah. Dengan seperti inilah maka Cristhoper Hood ${ }^{19}$ dari london school of Economics mengatakan bahwa new public management mengubah cara-cara dan model birokrasi publik yang tradisional ke arah cara-cara dan model bisnis privat dan perkembangan pasar. Cara-cara ligitimasi birokrasi publik untuk menyelematkan prosedur dari diskresi administrasi tidak lagi di praktikan oleh new public management dalam birokrasi pemerintah

Sementara manajemen publik baru (new public management) menurut Denhardt dan Denhardt memiliki ciri dominan sebagai berikut:

\footnotetext{
17 Owen E. Hughes, Op.cit., Hlm. 68-69.

18 David Osborne dan Ted Gaebler, Lo.cit.

19 C. Hood. II., Lo.cit.
} 
1. Pelaksanaan tugas manajemen pemerintahan lebih banyak diserahkan kepada para manajer professional.

2. Kinerja diukur dengan standard dan ukuran kinerja yang jelas.

3. Lebih ditekankan pada pengawasan dan penilaian hasil.

4. Pembagian tugas ke dalam unit kerja yang ada di level lebih bawah (desentralisasi).

5. Dikembangkan semangat persaingan dalam tubuh pemerintah.

6. Lebih menekankan penerapan gaya manajemen sektor swasta.

7. Lebih menekankan disiplin tinggi dan tidak boros dalam menggunakan berbagai sumber daya publik.

Untuk mewujudkan konsep new public management dalam birokrasi publik, maka di upayakan agar para pemimpin birokrasi meningkatkan produktifitas dan menemukan alternatif cara-cara pelayanan publik berdasarkan prespektif ekonomi. Mereka didorong untuk memperbaiki dan mewujudkan akuntabilitas publik kepada pelanggan, meningkatkan kinerja, restrukturisasi lembaga birokrasi publik, merumuskan kembali misi organisasi, melakukan stream lining proses dan prosedur birokrasi, dan melakukan desentralisasi proses pengambilan keputusan.
Dalam perkembangannya konsep NPM banyak mendapat kritik dari berbagai penulis. Diantaranya adalah Stewart dan Ranson, 1988; Pollit, 1990; Swiss, 1992; Frederickson, 1992. Mereka mempertanyakan validitas konsep pelanggan. Menurut mereka konsep pelanggan dalam konteks NPM tidak secara akurat menunjukan hubungan antara organisasi pemerintah dan anggota masyarakat (publik). Pendekatan NPM justru cenderung mereduksi makna warga negara (citizen) dengan menempatkan mereka sebagai penerima layanan yang pasif daripada agen yang aktif. Temuan ini tampaknya relevan dengan hasil kajian, ${ }^{20}$ bahwa orientasi bisnis dalam pelayanan publik dapat menyebabkan komersialisasi biaya pelayanan publik dimana biaya pelayanan yang real menjadi lebih besar daripada biaya sepantasnya yang harus dikeluarkan masyarakat. $^{21}$

Penerapan prinsip-prinsip paradigma manajemen publik baru ternyata tidak dibarengi dengan perubahan kultur dan mental aparatnya. Hal ini disebabkan alat-alat (tools) yang diguanakan sebagai representasi dari NPM ternyata hanya dijadikan sebagai hiasan semata. Standar pelayanan minimal tidak berfungsi demikian juga mekanisme pengaduan. Masyarakat tetap saja hanyalah sebagai pelanggan yang tidak diberikan hak

\footnotetext{
20 Agus Dwiyanto, (2006), Mewujudkan Good Geovernance Melalui Pelayanan Public, Yogyakarta; UGM Press, Hlm. (__ $)$.

21 Slamet Rosyadi, (2006), Kuncinya Melayani Masyarakat, Dalam Suara Merdeka, (__ ); (_ _), Hlm.
} 
untuk mengawasi. Siapa yang berani bayar mahal dia yang akan diuntungkan.

Perihal yang paling esensial dalam peningkatan kualitas pelayanan publik seiring bergulirnya paradigma demokratisasi pelayanan publik adalah adanya kesetaraan hubungan antara masyarakat pengguna jasa dengan aparat yang bertugas memberikan jasa pelayanan. Pelayanan publik hanya akan menjadi baik atau berkualitas apabila masyarakat yang mengurus sesuatu jenis pelayanan tertentu mempunyai posisi tawar yang sebanding dengan posisi tawar petugas pemberi layanan. ${ }^{22}$

Penguatan posisi tawar antara birokrasi dengan masyarakat merupakan hal penting yang harus dilakukan dalam rangka demokratisasi pelayanan publik. Prinsip ini sesuai dengan perkembangan paradigma yang sekarang bergulir dalam ranah disiplin ilmu administrasi publik. Paradigma the new public service (NPS) menawarkan nilai-nilai demokrasi yang harus dibangun oleh sebuah pemerintahan. Munculnya paradigma NPS sekaligus menjadi jawaban atas kelemahan yang ada, baik pada pendekatan administrasi publik tradisional (old publik administration) maupun manajemen publik baru (new public management). Dengan membuang sisi buruk OPA dan NPM, Denhardt dan Denhardt selanjutnya mengembangkan paradigma baru yang disebut new public service (NPS).
Paradigma NPS ini dibangun berdasarkan (1) theories of democratic citizenship, (2) models of community and civil society, (3) organizational humanism and the new public administration, and (4) post-modern public administration.

NPM pun kemudian dipertentangkan lagi dengan paradigma new public service (NPS). Paradigma ini mendasarkan diri pada teori-teori kewarganegaraan dan organisasi kemanusiaan dimana tugas negara adalah melayani masyarakat sebagai warga negara bukan lagi sebagai pelanggan. Prinsip ini sekali lagi diyakini sebagai prinsip yang lebih baik dari pada prinsip-prinsip sebelumnya.

Dalam perkembangan selanjutnya new public service (NPS) menjadi paradigma yang secara normatif paling mutakhir dan paling baik untuk bisa diterapkan dalam pelayanan publik di Indonesia. Pelayanan-pelayanan yang berbau bisnis sejauh ini perlu ditolak karena konsep ini mengandung neo manajerialisme yang memuat ancaman terhadap nilai-nilai demokrasi dan konstitusi, seperti mengancam kejujuran, keadilan, representasi dan partisipasi sehingga konsep ini hanya menang dari konsep pelayanan tradisional.

NPS adalah serangkaian ide tentang peranan administrasi publik dalam sistem pemerintahan yang menempatkan warga negara sebagai pusat pelayanan. Sebagai

22 Ratminto dan Atik Septi, (2005), Manajemen Pelayanan, Yogyakarta; Pustaka Pelajar, Hlm. 
konsep baru, NPS merupakan implikasi dari penempatan warga negara, kewarganegaraan dan kepentingan publik sebagai hal yang harus dikedepankan. Model ini sebenarnya menggugat secara fundamental NPM maupun EG. Teori ini muncul atas landasan teori sebelumnya seperti teori demokrasi citizen, teori pemberdayaan masyarakat sipil, teori organisasi yang humanis dan teori posmo administrasi publik.

Oleh karena dibangun dari inovasi praktis dan teoritical yang komprehensif, maka dari perspektif teori, konsep NPS terlihat lebih baik serta lebih dominan dibandingkan dengan dua konsep sebelumnya. Sehingga NPS mampu menghasilkan sebuah model yang normatif atau ideal dibandingkan dengan konsep yang lain. Sebagai model yang normatif, konsep NPS terlihat lebih konsisten dalam memberikan pondasi terhadap demokrasi di beberapa negara, meskipun penyediaan kerangka kerja pada nilai-nilai lain yang menyangkut teknis dan nilai pelayanan harus tetap disiapkan.

Dalam masyarakat demokrasi, perhatian nilai-nilai demokrasi harus diletakkan diatas segala-galanya, tetapi kita tetap harus berpikir tentang bagaimana sistem pemerintahan. Nilai efisiensi dan produktifitas tidak boleh ditinggalkan, tetapi harus diletakkan dalam konteks yang lebih luas pada demokrasi, komunitas dan kepentingan publik.
Berdasarkan prinsip utama dalam paradigma new public sevice tersebut, Denhardt dan Denhardt lebih lanjut menformulasikan delapan prinsip pelayanan yang harus diwujudkan agar pemerintah mampu memberikan pelayanan yang bermutu yaitu mencakup beberapa hal sebagai berikut.

\section{Convenience}

Ukuran yang menunjukkan sejauh mana pelayanan yang diberikan pemerintah dapat diakses dengan mudah oleh warga Negara.

2. Security

Ukuran yang menunjukan sejauh mana pelayanan yang diberikan pemerintah agar menjadikan warga merasa aman dan yakin untuk menggunakannya.

\section{Reliability}

Ukuran yang menunjukan sejauh mana pelayanan yang diberikan pemerintah dapat tersedia secara benar dan tepat waktu.

4. Personal Attention

Ukuran yang menunjukan sejauh mana pelayanan yang diberikan pemerintah dapat diinformasikan oleh aparat dengan tepat kepada warga dan aparat dapat bekerjasama dengan warga untuk membantu memenuhi kebutuhannya.

\section{Problem-Solving Approach}

Ukuran yang menunjukan sejauh mana aparat mampu menyediakan 
186 Yurispruden Volume 4, Nomor 2, Juni 2021, Halaman 175. -192.

informasi bagi warga untuk mengatasi masalahnya.

6. Fairness

Ukuran untuk menilai sejauh mana warga percaya bahwa pemerintah telah menyediakan pelayanan dengan cara yang adil bagi semua orang.

\section{Fiscal Responsibility}

Ukuran untuk menilai sejauh mana warga percaya bahwa pemerintah telah menyediakan layanan dengan menggunakan uang public dengan penuh tanggung jawab.

\section{Citizen Influence}

Ukuran sejauh mana warga merasa bahwa mereka dapat mempengaruhi mutu pelayanan yang mereka terima dari pemerintah.

Perwujudan kedelapan prinsip pelayanan yang bermutu di atas akhirnya akan sangat bergantung pada adanya komitmen dan keinginan yang kuat dari para aparat pemerintah untuk bisa mewujudkan prinsip pelayanan tersebut dengan benar dan sungguh-sungguh. Dengan demikian desentralitas struktur organisasi merupakan kadar organisasi dalam menciptakan relasi pekerjaan yang lebih fleksibel, lebih demokratis dan memiliki keseimbangan kekuasaan antar level dalam organisasi dalam memberikan pelayanan publik. Dengan struktur yang lebih flat maka penyelenggara layanan lebih bisa leluasa dalam mengambil kebijakan tanpa dibebani dengan hierarki yang melelahkan masyarakat.

NPS mendasarkan diri salah satunya kepada teori-teori kewarganegaraan demokratis. Teori ini melihat bahwa masyarakat pengguna jasa adalah sebagai citizen yang memiliki hak dan kewajiban sebagai warga negara. Hal tersebut akan sangat berimplikasi terhadap penguatan posisi tawar masyarakat terhadap pelayanan yang diberikan oleh birokrasi. Posisi tawar masyarakat akan meningkat apabila terdapat mekanisme bagi masyarakat untuk memiliki pilihan atas apa yang diinginkannya. Hal ini sejalan dengan pandangan NPS yang merekomendasikan adanya keterlibatan masyarakat dalam pelayanan publik. Karena pandangan ini menilai kepentingan publik berasal dari sebuah dialog mengenai nilainilai bersama, daripada kumpulan berbagai kepentingan individu. Oleh karena itu pelayan publik tidak semata-mata merespon berbagai tuntutan pelanggan, tetapi fokus pada hubungan yang dapat membangun kepercayaan dan kolaborasi dengan dan antar warga negara.

Faktor Pendukung dan Penghambat Penerapan Inovasi dan Kreativitas Public Service dalam Era Otonomi Daerah Sebagai Modern Local Government di Indonesia

1. The Dynamic Governance: Melembagakan Budaya, kemampuan dan 
Perubahan $^{23}$

Dynamic governance (DG) diperkenalkan oleh Boon Siong Neo dan Geraldine Chen dari National University of Singapore yang melihat fenomena perubahan yang terjadi dalam pemerintahan di Singapura. Prinsip DG adalah memberikan suatu kerangka kerja untuk mengungkap cara berpikir tentang bagaimana pemerintah mampu membuat keputusan yang baik, membawa mereka keluar dan merevisi berbagai keputusan tanpa krisis. Singapura menyediakan kasus luar biasa yang dapat digunakan untuk media pembelajaran kita. Pemerintah Singapura memiliki organisasi pemerintah yang sangat efisien. Kebijakan di Singapura selalu dibuat berdasarkan tujuan kemanfaatan yang jelas, bukan karena korupsi, ideologi atau kepentingan membesarkan diri sendiri. Birokrasi pemerintahannya sangat kritis diri.

Bagaimana hal tersebut bisa terjadi? Semua itu memerlukan seperangkat institusi pemerintah yang menggunakan kerangka kerja seperti yang dikemukakan dalam DG, yaitu institusi yang bisa berpikir kedepan (thinking ahead), berpikir ulang (thinking again), dan berpikir secara melintas (thinking across).
Terdapat karakteristik utama pada dynamic governance (DG). DG pada dasarnya merupakan penggabungan prinsip-prinsip yang ada dalam new public management dan new public service. Hal ini disebabkan karena dalam DG sangat memandang nilai-nilai kewarganegaraan (citizens) sebagai bagian yang penting. Dalam arti pemerintah harus hormat kepada warga negaranya dan keadaan lembaga yang mengatur interaksi sosial dan ekonomi. Namun pemerintah juga mendapatkan tekanan untuk memiliki semangat kewirausahaan dengan cara mengurangi penggunaan peraturan dan kekuasaan yang terlalu memaksa. Dengan demikian pemerintahan yang dinamis adalah pemerintahan yang mampu menghargai hak dan kewajiban warga negaranya namun dengan tetap memberikan pelayanan yang bersaing dan selalu berfikir inovatif dan kreatif.

DG tidaklah terjadi secara kebetulan, namun merupakan hasil dari kepemimpinan yang memiliki komitmen kuat serta ambisi untuk mencapai tujuan nasional melalui interaksi struktur sosial dan ekonomi. Hal ini menunjukan adanya kepemimpinan yang secara sengaja berupaya untuk membentuk masa depan negara. DG adalah hasil dari sebuah kemampuan atau kapasitas dalam hal

23 Boon Siong Neo dan Geraldine Chen, (2007), Dynamic Governance, Embedding Culture, Capabilities and Change in Singapore, Singapore; World Scientific Publishing, Hlm. 
188 Yurispruden Volume 4, Nomor 2, Juni 2021, Halaman 175. -192.

pengembangan cara-cara (jalur) yang adaptif serta kebijakan yang adaptif pula yang juga harus diikuti adanya implementasi yang efektif.

Hasil yang diinginkan dengan adanya DG adalah adanya perubahanperubahan dalam pemerintahan yang semua itu akan tercapai jika kebijakan adaptif sudah dilaksanakan. Dasar dari DG yang menjadi landasan utama adalah budaya institusi yang terdiri dari incorruptability, meritokrasi, markets, pragmatism, multi-rasialism, state activism, long term, relevance, growth, stability, prudence, self-reliance. Dalam DG terdapat 3 elemen penting yang harus dijalankan oleh pemerintah. Yaitu berpikir kedepan, berpikir ulang dan berpikir melintasi batasan tertentu. Dimana semua itu dilakukan untuk menghasilkan pembuatan kebijakan yang lebih adaptif.

Terdapat dua pengungkit utama untuk mengembangkan DG yaitu orangorang yang memiliki kemampuan (able people) dan adanya proses yang tangkas (agile processes). Kinerja organisasi masih menjadi doktrin penting dalam DG, selain itu juga adanya proses yang tanggap terhadap perubahan juga sangat penting untuk menangkap permasalahan yang di hadapi dan mengantisipasi masa depan yang penuh ketidakpastian.

Selain itu untuk mencapai DG pemerintah juga harus selalu tanggap terhadap dampak lingkungan eksternal yang membuat negara memiliki ketidakpastian masa depan serta adanya fenomena-fenomena eksternal yang memiliki dampak tertentu. Sehingga memang ketidakpastian masa depan harus diatasi dengan pola pikir thinking ahead dari pemerintah. Sedangkan banyaknya perkembangan praktis di luar sana harus diantisipasi dengan selalu thinking across sehingga kita akan dapat menerima pandangan lain dari dunia disekeliling kita. Sehingga elemen penting yang harus ada dalam DG adalah:

a. Capability (thinking ahead, thinking again dan thinking across).

b. Culture.

c. Change (inovasi dan kebijakan yang adaptif).

Pola transformasi yang dikehendaki dalam DG adalah merubah sistem yang terdapat dalam sebuah pemerintah. Mulai dari inputnya sampai dengan outputnya. Transformasi dilakukan dengan cara memahami dan mengembangkan potensi dari sumber daya manusia sebagai input dengan cara yang disengaja. Hal ini dilakukan untuk menggali potensi yang dibutuhkan dalam kinerja. Jadi yang diutamakan adalah pengembangan potensi.DG sangat mengutamakan proses dalam sebuah sistem organisasi. Sehingga hasil yang baik merupakan dampak dari adanya proses yang baik. DG juga sangat 
mengutamakan gagasan-gagasan sebagai input yang mendorong kreativitas.

Pentingnya sebuah pemerintahan yang diwakili oleh agen-agen untuk mengembangankan jaringan. Karena seringkali masalah yang signifikan dan kesempatan berdiri secara independen. Disamping adanya koordinasi yang baik dalam implementasi kebijakan juga perlunya koordinasi untuk melihat visi ke depan. Pemerintah harus senantiasa membuka diri dengan pandangan warga negaranya terkait visi negara ke depan. Manajemen pemerintahan sangat mengedepankan kepemimpinan yang memiliki visi yang jelas, keyakinan yang kuat dan nilai-nilai etika.

2. The Sound Governance: Policy and Administrative Innovations ${ }^{24}$

Konsep sound governance (SG) digunakan sebagai rujukan bagi reformasi birokrasi karena pertama, konsep ini dipandang lebih komprehensif dibandingkan dengan konsep sebelumnya. SG memasukkan pentingnya aspek global dan lembaga internasional bagi tata pemerintahan yang yang baik. Kedua, SG juga mencakup suatu aspek normatif sebaik sisi teknis dan rasionalitas yang ada dalam konsep good governance. Ketiga, konsep SG ini memiliki semua karakteristik tata pemerintahan yang lebih unggul dibandingkan dengan konsep good governance dan suara disini menggambarkan aspek teknikal, profesionalitas, organisasional, manajerial, politik, demokrasi, dan ekonomi. Suara juga meliputi kemampuan, dan perilaku antisipatif, responsivitas dan kompetensi. Dan nilainilai ini tertanam dalam budaya sebagai social values dan struktur. Keempat konsep SG sesuai dengan nilai-nilai konstitusional dan responsif terhadap norma-norma internasional, aturan dan juga rezim. Good governance seperti yang didefinisikan para pendukungnya telah mengabaikan aspek penting ini. Kelima, konsep SG telah berkembang lama pada saat kekaisaran Persia. Konsep ini menghasilkan efisiensi dan efektivitas yang tinggi dalam penyelenggaraan sistem administrasi pada waktu itu.

Sound governance memiliki beberapa dimensi yang meliputi (1) proses; (2) struktur; (3) kognisi dan nilainilai; (4) konstitusi; (5) organisasi dan lembaga; (6) manajemen dan kinerja; (7) kebijakan; (8) sektor; (9) internasional atau globalisasi kekuatan; dan (10) etika, akuntabilitas, dan transparansi. Setiap dimensi bekerja sama satu dengan lainnya menjadi seperti sebuah orkestra, dengan kepemimpinan yang sesuai SG yaitu

24 Ali Farazmand, (2004), Sound Governance in the Age of Globalization: A Conceptual Framework”, dalam Ali Farazmand, Eds; Sound Governace: Policy and Administrative Innovation, 
dinamis, interaktif, dan partisipatif unsurunsur atau komponen yang diuraikan di atas, memberikan kualitas sistem pemerintahan di luar dugaan.

Dalam implemntasinya konsep ini digunakan untuk menghadapi era perubahan atau globalisasi yang tidak bisa kita hindarkan. Birokrasi pemerintah dengan melihat pentingnya norma internasional dapat lebih bisa mengantisipasi perubahan. Inovasi adalah kunci menuju sound governance. Inovasi yang harus dilakukan menuju SG adalah inovasi dalam kebijakan dan juga administrasi sebagai sentral dari governance. Tanpa inovasi kebijakan dan administratif, pemerintahan akan mengalami ineffectiveness, kehilangan kemampuan dalam pemerintahan dan menjadi banyak dikritik karena gagal menjalankan tugasnya. Esensi penting untuk mencapai SG adalah melalui inovasi teknologi, sumber daya pembangunan, sistem komunikasi, organisasi dan manajemen, pelatihan dan pengembangan, dan juga penelitian.

Inovasi kebijakan dalam pemerintahan sangat penting untuk proses adaptasi dan penyesuaian terhadap lingkungan yang berubah dengan cepat akibat era globalisasi. Hal ini juga merupakan upaya untuk meningkatkan kapasitas pemerintahan seperti yang terdapat dalam dimensi SG. Kegagalan berinovasi berarti kegagalan dalam beradaptasi, gagal dalam meningkatkan kapasitas dan juga gagal menjadi pemerintahan yang efektif. Demikian pula dengan inovasi administrasi dalam hal ini struktur organisasi juga penting bagi organisasi dan manajemen dalam sebuah pemerintahan dan untuk pelaksanaan inovasi kebijakan yang efektif. Artinya tanpa inovasi dan adaptivitas administrasi dan manajerial, maka inovasi kebijakan akan sulit dijalankan. Misalnya dalam inovasi kesehatan gratis bagi rakyat miskin pasti akan sangat memerlukan sistem pendataan yang akurat dan jelas sehingga sistem administrasi harus dirubah dari yang tradisional menjadi modern.

\section{KESIMPULAN}

Inovasi dan kreativitas adalah kunci untuk melakukan reformasi birokrasi. Reformasi ini diperlukan untuk menghadapi perubahan terutama di masa globalisasi dan perubahan yang cepat. Kreativitas merupakan syarat terjadinya inovasi. Sehingga apabila birokrasi ingin melakukan perubahan, maka berikanlah ruang bagi kreativitas birokrasi. Dari kreativitas inilah kemudian akan memunculkan ide-ide inovatif. Peluang untuk memberikan keleluasaan bagi aparatur birokrasi dapat dilakukan melalui upaya diskresi yang selama ini kita kenal. Kebijakan yang dibuat sebisa mungkin masih memberi 
peluang birokrasi untuk melakukan upaya diskresi. Dikresi dapat berperan untuk mengisi, melengkapi dan mengembangkan suatu kebijakan hingga dapat diimplementasikan.

Beberapa ide dan wacana yang telah dijelaskan, secara mendasar melihat inovasi dalam birokrasi bisa dilakukan pada sistem administrasi yang terdiri dari banyak hal seperti manajerial, kelembagaan, organisasi, budaya, dan teknologi dan sebagainya. Inovasi dan kreativitas birokrasi juga akan mengubah proses pemerintahan dan juga struktur organisasi. Hal ini akan membantu membangun dan meningkatkan manajerial, administratif, dan kapasitas pemerintahan, tidak hanya untuk menjaga performa tinggi, tetapi juga dalam cara antisipasi untuk memenuhi tantangan zaman globalisasi.

\section{DAFTAR PUSTAKA}

\section{Peraturan Perundang-Undangan}

Undang-Undang Dasar 1945.

Undang-Undang Nomor 25 Tahun 2009 Tentang Pelayanan Publik.

Undang-Undang Nomor 23 Tahun 2014 Tentang Pemerintahan Daerah.

Undang-Undang Nomor 9 Tahun 2015 Tentang Perubahan Kedua Atas UndangUndang Nomor 23 Tahun 2014 Tentang Pemerintahan Daerah.

Peraturan Pemerintah Nomor 38 Tahun 2017 Tentang Inovasi Daerah.

\section{Buku}

Agus Dwiyanto, (2006), Mewujudkan Good Geovernance Melalui Pelayanan Public, Yogyakarta; UGM Press.
Ali Farazmand, (2004), Sound Governance in the Age of Globalization: A Conceptual Framework", dalam Ali Farazmand, Eds; Sound Governace: Policy and Administrative Innovation, (__ ); (_ _ ).

B. Guy Peters, (1995), The Politics of Bureaucracy, Massachusetts; Addison Wesley.

Boon Siong Neo dan Geraldine Chen, (2007), Dynamic Governance, Embedding Culture, Capabilities and Change in Singapore, Singapore; World Scientific Publishing.

Christopher Pollitt (1990), Managerialism and the Public Services: The AngloAmerican Experience. Cambridge, Massachusetts; Basil Blackwell.

David Osborne dan Ted Gaebler, (1992), Mewirausahakan Birokrasi Mentransformasi Semangat Wirausaha Ke Dalam Sektor Publik, Jakarta; PPM.

Denhardt dan Denhardt, (2003), The New Public Service, Serving not Steering, New York; M.E. Sharpe, Armonk.

Keban Yeremis T, (2014), Enam Dimensi Strategis Administrasi Publik, Konsep, Teori dan Isu.

Mifta Thoha, (2015), Ilmu Administrasi Publik Kontemporer, Jakarta; Prenadamedia Group.

Owen E. Hughes, (1994), Public Management and Administration: An Introduction, London: The MacMillan Press Ltd.

Ratminto dan Atik Septi, (2005), Manajemen Pelayanan, Yogyakarta; Pustaka Pelajar.

Slamet Rosyadi, (2006), Kuncinya Melayani Masyarakat, Dalam Suara Merdeka, (_ $)$; ( _ $)$.

\section{Jurnal}

Bhennyamin Hoessein, (2021), Hubungan Penyelenggaraan Pemerintahan Pusat dengan Pemerintahan Daerah, Jurnal Bisnis dan Birokrasi, Vol. 1, No. 1. 
192 Yurispruden Volume 4, Nomor 2, Juni 2021, Halaman 175. -192.

C. Hood, (1991), A Public Management for

All Seasons? Public Administration, Spring, Vol. ), No. (

(1995), The NPM in the 1980s: Variations on a Theme, Accounting, Organisation and Society, Vol. 2, No. 3. 